\title{
A Major Genetic Factor at Chromosome 9p Implicated in Amyotrophic Lateral Sclerosis (ALS) and Frontotemporal Lobar Degeneration (FTLD)
}

\author{
Ilse Gijselinck ${ }^{1,2}$, Kristel Sleegers ${ }^{1,2}$, \\ Christine Van Broeckhoven ${ }^{1,2}$ and Marc Cruts ${ }^{1,2}$ \\ ${ }^{1}$ Department of Molecular Genetics, VIB, Antwerpen \\ ${ }^{2}$ University of Antwerp, Antwerpen \\ Belgium
}

\section{Introduction}

Amyotrophic lateral sclerosis (ALS) and frontotemporal lobar degeneration (FTLD) are two fatal neurodegenerative diseases for which effective therapies aiming at delaying, halting or preventing the disease are lacking. ALS is the most common motor neuron disorder (Rowland \& Shneider, 2001) and FTLD has a prevalence close to that of Alzheimer disease in the population below age 65 years (Rosso et al., 2003). They are considered as both extremes of a spectrum of clinically and pathologically overlapping disorders (Lillo \& Hodges, 2009). In addition, there is emerging evidence that FTLD and ALS also share common genetic aetiologies, suggesting that overlapping disease mechanisms are involved in both diseases. Clinically, ALS patients show reduced control of voluntary muscle movement expressed in increased muscle weakness, disturbances of speech, swallowing or breathing, as a result of progressive upper and lower motor neuron degeneration in motor cortex, brainstem and spinal cord, and up to $50 \%$ of ALS patients shows mild disturbances in executive functions while a minority also develop overt FTLD (Lomen-Hoerth et al., 2003; Ringholz et al., 2005). FTLD symptoms include behavioural, personality and language disturbances, and also cognitive dysfunctions, due to affected frontal and temporal cortical neurons in the brain. FTLD patients may additionally present with typical clinical signs of ALS in a later stage of the disease (Neary et al., 1998). Pathologically, although in different neuronal cells, TAR DNA-binding protein-43 (TDP-43) is a major constituent of neuronal deposits in both ALS and TDP-43 positive FTLD (FTLD-TDP), the most common pathological FTLD subtype (Arai et al., 2006; Neumann et al., 2006). Five to $10 \%$ of ALS patients and up to $50 \%$ of FTLD patients has a positive familial history of disease with a Mendelian mode of inheritance indicating a significant contribution of genetic factors in disease aetiology. Although the exact biochemical pathways involved in ALS or FTLD are still unknown, several molecular components were identified in the last twenty years through molecular genetic studies in familial and sporadic patients, which are most likely part of a complex network of cellular mechanisms. Since these genes explain only a minority of patients, further unraveling the 
genetic heterogeneity is necessary to identify new therapeutic targets. Mutations causing ALS were observed in genes encoding $\mathrm{Cu} / \mathrm{Zn}$ superoxide dismutase 1 (SOD1) (Rosen et al., 1993), TDP-43 (TARDBP) (Gitcho et al., 2008; Kabashi et al., 2008; Sreedharan et al., 2008; Van Deerlin et al., 2008; Yokoseki et al., 2008), fused in sarcoma (FUS) (Kwiatkowski, Jr. et al., 2009; Vance et al., 2009) and angiogenin (ANG) (Greenway et al., 2006), among other genes, while in familial FTLD patients mutations in the genes encoding granulin (GRN) (Baker et al., 2006; Cruts et al., 2006), the microtubule-associated protein tau (MAPT) (Hutton et al., 1998), the valosin-containing protein (VCP) (Watts et al., 2004) and the charged multivesicular body protein 2B (CHMP2B) (Skibinski et al., 2005) were found. Recent family-based linkage and population-based association studies identified genetic factors overlapping between ALS and FTLD. For example, mutations in the ALS genes TARDBP and FUS are occasionally found in FTLD patients (Kovacs et al., 2009; Van Langenhove et al., 2010) and mutations in the FTLD gene VCP were also detected in ALS (Johnson et al., 2010). However, most convincing evidence for the genetic overlap comes from the observation that both ALS and FTLD can occur within the same family or within a single patient of a family. More than 15 autosomal dominant families with ALS and FTLD worldwide are causally linked with a major disease locus at chromosome 9p13-p21 (ALSFTD2 locus) (Boxer et al., 2010; Gijselinck et al., 2010; Le Ber et al., 2009; Luty et al., 2008; Momeni et al., 2006; Morita et al., 2006; Pearson et al., 2011; Valdmanis et al., 2007; Vance et al., 2006). The minimally linked region in all these families is about $3.6 \mathrm{Mb}$ in size containing five known protein-coding genes. Moreover, several recent genome-wide association studies (GWAS) in ALS populations from different European origins showed the presence of a major genetic risk factor for ALS at the same chromosome $9 p$ region (Laaksovirta et al., 2010; Shatunov et al., 2010; van Es et al., 2009). The Finnish study narrowed the associated region to a $232 \mathrm{~kb}$ linkage disequilibrium (LD) block containing three known genes (MOBKL2B, IFNK, C9orf72) and suggested the presence of a major risk gene with high penetrance (Laaksovirta et al., 2010). Likewise, a GWAS in FTLD has implicated the same region (Van Deerlin et al., 2010). This finding was further confirmed in other FTLD and ALS-FTLD cohorts (Rollinson et al., 2011). Together, these data demonstrate that ALS and FTLD share a major common genetic factor on chromosome 9p, most likely showing high mutation frequencies. Despite all attempts of several research groups, the genetic defect(s) underlying both genetic linkage and association to this region have not been identified yet.

In this book chapter we will report and discuss the latest findings in the studies aiming at identifying the chromosome 9 gene defect.

\section{Family-based linkage to ALSFTD2 locus on chromosome 9p}

Since the original reports of a Dutch and a Scandinavian ALS-FTLD family linked with chromosome 9p21 (Morita et al., 2006; Vance et al., 2006), a growing number of families with inherited ALS and FTLD are reported with significant linkage to the ALSFTD2 locus on chromosome 9p21 (Boxer et al., 2010; Gijselinck et al., 2010; Le Ber et al., 2009; Luty et al., 2008; Valdmanis et al., 2007) (table 1). In all these families patients show similar clinical and pathological characteristics. Clinically, individuals may present with symptoms of both ALS and FTLD, or with ALS or FTLD alone. Pathologically, autopsied patients have TDP-43 positive type 2 (Sampathu et al., 2006) brain inclusions (Boxer et al., 2010; Gijselinck et al., 2010; Le Ber et al., 2009; Luty et al., 2008; Morita et al., 2006; Vance et al., 2006). (table 1) 
The minimal candidate region was previously defined by D9S169 (Luty et al., 2008) and D9S1805 (Valdmanis et al., 2007) spanning $7 \mathrm{Mb}$ and was recently reduced to $3.6 \mathrm{Mb}$ between D9S169 (Luty et al., 2008) and D9S251 by Boxer and colleagues (2010) (figure 1). Therefore, several parts of this study were still investigated in the $7 \mathrm{Mb}$ region.

\begin{tabular}{|c|c|c|c|c|c|c|c|c|c|}
\hline Family & Origin & $\begin{array}{l}\text { Max } \\
\text { LOD } \\
\text { score } \\
\text { at } \\
9 \mathrm{p} 21\end{array}$ & $\begin{array}{l}\text { Mean onset } \\
\text { age in years } \\
\text { (range) }\end{array}$ & $\begin{array}{l}\text { Mean } \\
\text { disease } \\
\text { duration } \\
\text { in years } \\
\text { (range) }\end{array}$ & $\begin{array}{l}\text { TDP- } \\
43+\end{array}$ & \# ALS & $\begin{array}{l}\# \text { ALS } \\
+ \\
\text { FTLD }\end{array}$ & \# FTLD & References \\
\hline Luty & Australian & 3.41 & $53(43-68)$ & $9(1-16)$ & + & 2 & 2 & 7 & $\begin{array}{l}\text { (Luty et al., } \\
2008 \text { ) }\end{array}$ \\
\hline DR14 & Belgian & 3.38 & $58.1(51-65)$ & $6.4(1-17)$ & + & 1 & 0 & 10 & $\begin{array}{l}\text { (Gijselinck } \\
\text { et al., 2010) }\end{array}$ \\
\hline F2 & Dutch & 3.02 & $60.3(39-72)$ & $3.0(1-8)$ & ND & 7 & 3 & 2 & $\begin{array}{l}\text { (Vance et } \\
\text { al., 2006) }\end{array}$ \\
\hline Que23 & Canadian & 3.01 & $55.8(46-58)$ & $2.4(1.5-3)$ & ND & 5 & 0 & 3 & $\begin{array}{l}\text { (Valdmanis } \\
\text { et al., 2007) }\end{array}$ \\
\hline VSM20 & Irish & 3.01 & $45.7(35-57)$ & $5.4(3-10)$ & + & 2 & 3 & 5 & $\begin{array}{l}\text { (Boxer et al., } \\
2010 \text { ) }\end{array}$ \\
\hline F438 & Scandinavian & 3.00 & $55.3(45-64)$ & $4.3(1-9)$ & ND & 5 & 0 & 9 & $\begin{array}{l}\text { (Morita et } \\
\text { al., 2006) }\end{array}$ \\
\hline 6 families & French & $8.0^{1}$ & $57.9(40-84)$ & $3.6(1-8)$ & + & 9 & 12 & 10 & $\begin{array}{l}\text { (Le Ber et } \\
\text { al., 2009) }\end{array}$ \\
\hline Que1 & $\begin{array}{l}\text { French- } \\
\text { Canadian }\end{array}$ & 2.51 & $54.3(45-63)$ & $4.8(2-9)$ & ND & 5 & 3 & 0 & $\begin{array}{l}\text { (Valdmanis } \\
\text { et al., 2007) }\end{array}$ \\
\hline Fr104 & Spanish & 1.55 & ND & ND & ND & 4 & 1 & 0 & $\begin{array}{l}\text { (Valdmanis } \\
\text { et al., 2007) }\end{array}$ \\
\hline F2 & $\begin{array}{l}\text { North- } \\
\text { American }\end{array}$ & 1.5 & ND & ND & ND & 0 & 7 & 0 & $\begin{array}{l}\text { (Momeni et } \\
\text { al., 2006) }\end{array}$ \\
\hline Gwent & Brittish & ND & $42.2(31-52)$ & $3.6(1-13)$ & + & 3 & 6 & 0 & $\begin{array}{l}\text { (Pearson et } \\
\text { al., 2011) }\end{array}$ \\
\hline F476 & $\begin{array}{l}\text { North- } \\
\text { American }\end{array}$ & ND & ND & ND & ND & 2 & 3 & 0 & $\begin{array}{l}\text { (Momeni et } \\
\text { al., 2006) }\end{array}$ \\
\hline ALS_A & American & ND & $?(35-73)$ & $?(0.5-5)$ & ND & 6 & 0 & 0 & $\begin{array}{l}\text { (Krueger et } \\
\text { al., 2009) }\end{array}$ \\
\hline
\end{tabular}

Table 1. Genetic, clinical and pathological characteristics of ALS-FTLD families linked or associated with chromosome 9p21 (ND: not determined; ${ }^{1}$ summed LODscore in 6 small families, not linked separately) 


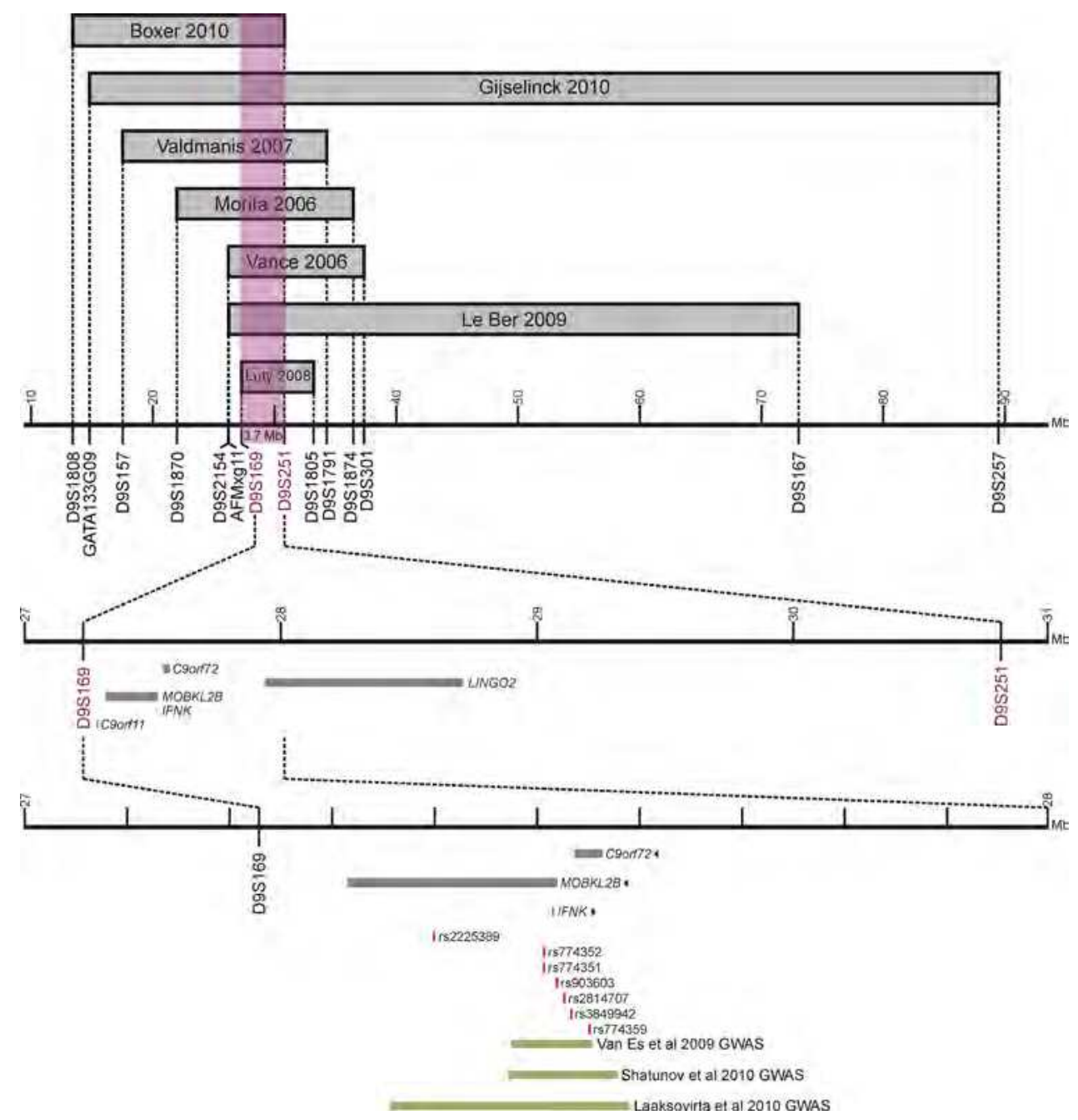

Fig. 1. Schematic representation of the chromosome 9p21 ALS-FTLD locus. Upper panel: grey bars indicate the minimal candidate regions in all reported significantly linked ALSFTLD families, defining a minimal interval of 3.7 Mb between D9S169 and D9S251 containing five protein coding genes, illustrated with grey lines. Lower panel: associated SNPs in ALS and FTLD GWAS are shown in red and LD blocks or finemapped regions of these GWAS are indicated with green lines. Three genes are located in the associated region. 


\subsection{Family DR14}

We studied a Belgian 4-generation family (family DR14) with autosomal dominant transmission of ALS and FTLD. We collected DNA from 29 family members of whom 3 patients in generation III and 11 at-risk individuals in generation III and IV each (figure 1). Two patients (III.2 and III.12) were diagnosed with FTLD (subtype FTD), while patient III.10 was diagnosed with ALS (figure 2). The mean age at onset was $58.1 \pm 4.2$ years $(\mathrm{N}=9$, range 51-65 years) and mean disease duration was $6.4 \pm 4.9$ years (range 1-17 years). The index patient was clinically diagnosed with familial FTLD (subtype FTD) and pathological TDP-43 positive inclusions were observed in the brain (FTLD-TDP type 2 (Sampathu et al., 2006)). Mutations in the known genes for ALS and dementia were excluded. (Gijselinck et al., 2010)

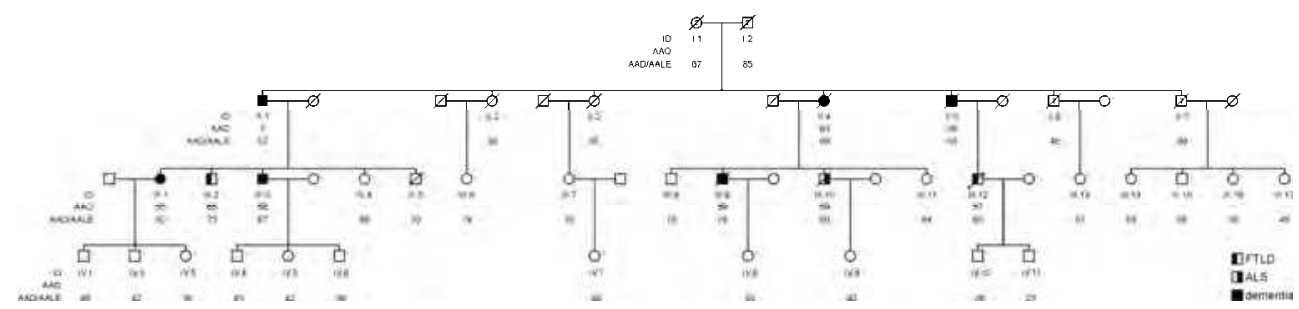

Fig. 2. The pedigree of DR14 consists of four generations. Left-filled and right-filled symbols represent patients with FTLD and ALS respectively. Patients with unspecified dementia are indicated with filled symbols. Open symbols represent unaffected individuals or at-risk individuals with unknown phenotype. Individuals with unclear phenotype are designated with a question mark (?). The arrow indicates index patient III.12. Numbers below the symbols denote age at onset and age at death (AAD) for patients and either age at last examination (AALE) or AAD for unaffected individuals or individuals with unknown phenotype. An asterisk $\left(^{*}\right)$ indicates individuals of whom DNA was available.

\subsection{Mutation analyses of known genes and conserved regions, and CNV analysis}

We performed a genome-wide scan using an in-house developed mapping set of 425 microsatellite markers in 30 multiplex panels with an average distance of $8 \mathrm{cM}$. Multipoint LOD scores were calculated revealing two loci on chromosome 9 and 14: one at chromosome 9 with a maximal LOD score of 2.71 between D9S1121 and D9S270 and one at chromosome 14 with the highest LOD score of 2.61 between D14S302 and D14S611. Finemapping of the chromosome 9 locus resulted in a significant maximal multipoint LOD score of 3.38 between D9S1833 and D9S1121 at 9p21 and segregation analysis defined a candidate region of 64.6 cM $(74.7 \mathrm{Mb})$ between markers D9S235 and D9S257 on chromosome 9p23-9q21, based on two obligate recombinants (figure 3), harboring 271 protein coding genes (Gijselinck et al., 2010). This region overlaps with the ALSFTD2 locus at chromosome 9p21 but did not reduce the minimally linked region. Therefore, we analyzed the $7 \mathrm{Mb}$ overlap region, including the minimal locus of $3.6 \mathrm{Mb}$, for mutations. We sequenced all 27 protein-coding genes, either the complete coding sequence of cDNA ( $\mathrm{N}=17)$ including $M O B K L 2 B, C 9$ orf $72, A C O 1, D D X 58$, TOPORS, NDUFB6, DNAJA1, SMU1, B4GALT1, BAG1, CHMP5, AQP3, NOL6, UBE2R2, $U B A P 2, W D R 40 A$ and UBAP1, or the exons and exon-intron boundaries on gDNA using classical sequencing $(\mathrm{N}=10)$. cDNA was prepared from lymphoblasts of two patients and two healthy control individuals of the family not carrying the disease haplotype, treated with or without cycloheximide allowing also the detection of degraded aberrant transcripts. 
Mutation analysis on cDNA allows not only detecting simple point mutations and small insertions/deletions but also exon deletions/duplications and alternative transcripts. Similar to other chr9-linked ALS-FTLD families, this mutation analysis did not reveal patient-specific novel variants segregating with disease.

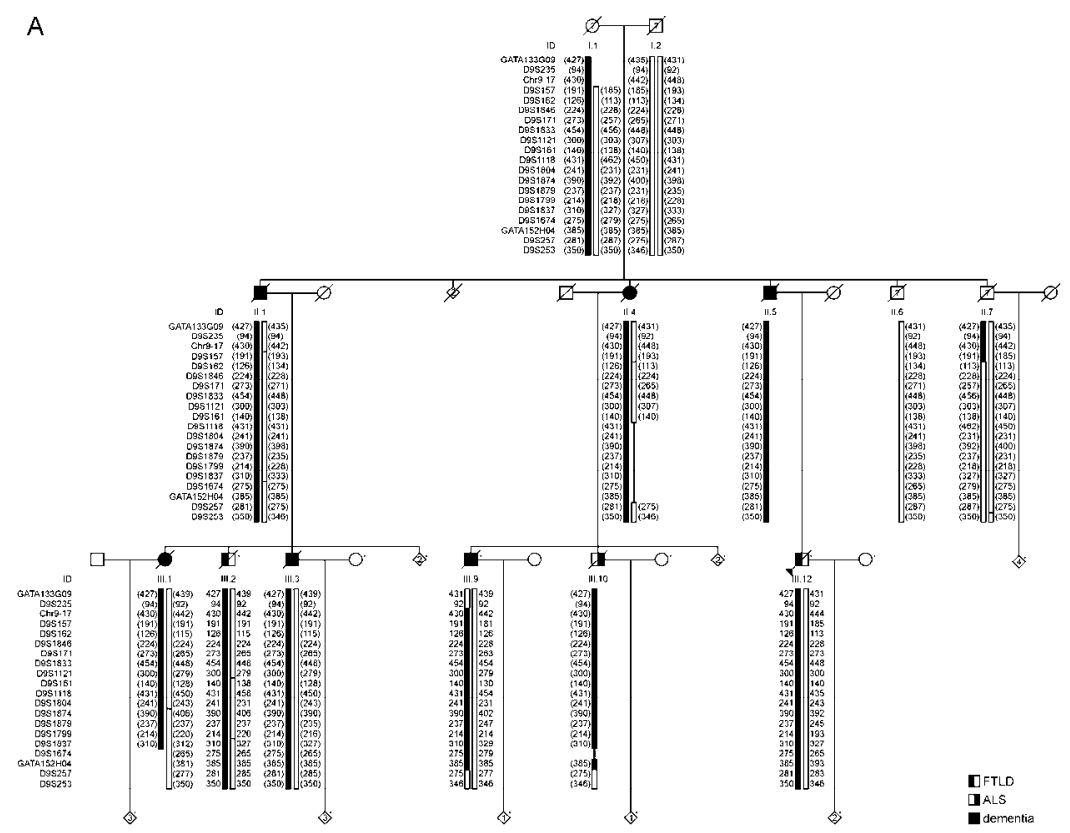

Fig. 3. Segregation of the 9p23-q21 haplotype in family DR14. Haplotypes are based on a selection of 20 informative STR markers at chromosome 9. The black haplotype represents the disease haplotype. Haplotypes for deceased individuals were inferred based on genotype data obtained in their offspring (between brackets). The disease haplotype was arbitrarily set for I.1, and numbers in diamonds indicate the number of genotyped at-risk individuals. An asterisk (*) indicates individuals of whom DNA was available.

Since all coding exons of known genes were excluded for mutations, we selected other evolutionary conserved regions and investigated these sequences for the presence of noncoding variants in evolutionary constrained regulatory elements, e.g. promoters and distant regulatory elements or conserved epigenetic sequence motifs, or coding variants in unknown novel genes (protein coding or non-coding RNA genes). Using the UCSCPhastCons-mammalian-28way track predicting and scoring the presence of conserved elements in the genome by comparing the sequence between 28 mammalian species, we defined $149 \mathrm{~kb}$ of conserved elements throughout the ALSFTD2 locus of $7 \mathrm{Mb}$. These elements were grouped in 1108 clusters with a total sequence of $465 \mathrm{~kb}$ and ranked according to conservation strength. We performed sanger sequencing in two patients and two healthy control individuals of the family not carrying the disease haplotype. In total we sequenced $95 \mathrm{~kb}$ of highest conserved elements (total of $260 \mathrm{~kb}$ clusters) in the $7 \mathrm{Mb}$ region, not revealing patient-specific novel variants segregating with disease. Of these, $61 \mathrm{~kb}$ of conserved regions are located in the minimal candidate region of $3.6 \mathrm{Mb}$. Using this 
approach, we excluded mutations in highly conserved regions. However, we did not exclude variants in regions with no or low conservation in mammalian species because it is well known that a substantial number of primate/human-specific exons exist (e.g. Sela et al., 2007) and that the location of regulatory elements is not always highly conserved, even not in mammals e.g. between human and mouse (Ravasi et al., 2010).

In addition, we performed chromosome-specific oligo-based array-comparative genomic hybridization (array-CGH, Nimblegen) at chromosome 9 with a resolution of about $1 \mathrm{~kb}$, on the index patient and an independent control individual not carrying the disease haplotype to detect copy number variations (CNVs). The $\mathrm{CGH}$ data were analyzed by Signalmap software (Nimblegen) and the scoring program CGHcall, revealing one large CNV (chr9:29082732-29087816) covered by 20 CGH probes. This deletion was confirmed in the index patient by six qPCR fragments demonstrating a deleted region of at least $5273 \mathrm{bp}$ (chr9:29082677-29087949) (data not shown). It did not segregate with disease in DR14 and represented a polymorphism since it was also present in individuals not carrying the disease haplotype and since a frequent $\mathrm{CNV}$ had previously been reported at this position (chr9:29082445-29088195) (Cooper et al., 2008). Consequently, these experiments failed to identify a copy number mutation (deletion or insertion) of more than $1 \mathrm{~kb}$ (Gijselinck et al., 2010). Cytogenetics excluded large chromosomal rearrangements.

Since all these mutation analyses did not reveal the causal mutation, we hypothesized that the mutation is most likely unusual with respect to location (extragenic or intronic) and/or type (small indel, inversion or other complex rearrangement). Therefore, we performed whole genome sequencing in family DR14 and subsequently analyzed sequences or variants in the linked region.

\subsection{Whole genome sequencing}

The complete genome sequence of four chromosome $9 p$ disease haplotype carriers of family DR14, including two patients and two asymptomatic individuals was determined using next generation sequencing technology. These family members were selected such that they have a different unaffected haplotype. The sequencing was done with the company Complete Genomics (Mountain View CA, USA, www.completegenomics.com) who provides 35 bp paired-end sequence reads at a high sequence coverage obtained with high-accuracy combinatorial probe anchor ligation (cPAL) sequencing technology (Drmanac et al., 2010; Roach et al., 2010). Also, the paired-end sequencing data enable the identification of copy number variations (CNVs) and other structural variants (SV) including inversions, in addition to single nucleotide polymorphisms (SNPs).

In the 4 genomes, we obtained an average coverage of 62 -fold genome sequence and captured both alleles at $95.4 \%$ of the genomes. All sequence variants, including SNPs and small indels, were mapped to the human reference genome sequence (NCBI Build $36 /$ hg18). We initially focused on the $3.6 \mathrm{Mb}$ candidate region on chromosome 9p21. We filtered and prioritized variants according to several criteria. First, variants must be present heterozygously in all 4 patients since the disease is segregating in an autosomal dominant manner. As a heterozygous variant might be rarely missed using NGS technology, depending on local sequence coverage and quality, variants detected in three of four patients were also considered. Second, variants were selected that were not catalogued in the dbSNP database (http://www.ncbi.nlm.nih.gov/projects/SNP) and were not found as common polymorphisms (allele frequency $\geq 1 \%$ ) in the 1000 Genomes 
Project (http://www.1000genomes.org). Third, variants in nucleotide stretches were filtered out because they are known to be error-prone in NGS data. This resulted in a total of 189 variants, all located outside coding regions of known genes confirming genebased mutation analyses. These variants were genotyped in all 29 individuals of the DR14 family using Sanger sequencing and tested for segregation. 120 variants were located on the disease haplotype and were analyzed in a series of 300 neurologically healthy control individuals collected in Flanders, Belgium, i.e. the geographical region of which family DR14 originates, using multiplex Sequenom MassARRAY technology. 37 of these variants were completely absent in 300 control individuals and are all located in untranslated regions or introns of genes, or intergenic. We are currently prioritizing these variants based on evolutionary conservation, regulatory potential, location compatible with cis-acting function on functional candidate genes, etc. Also, we are determining the presence of these variants in a Belgian population of unrelated patients with ALS ( $\mathrm{N}=124)$, ALS-FTLD ( $\mathrm{N}=21)$ and FTLD $(\mathrm{N}=203)$, aiming to find a possible founder mutation. We already showed evidence for the presence of founder mutations in the Flanders-Belgian FTLD collection, by the GRN IVS1+5 G>C founder mutation identified in 19\% of familial FTLD (Cruts et al., 2006). We have investigated the patient population for chromosome 9p STR markers and did not find evidence for haplotype sharing with family DR14; however, we cannot exclude the presence of a small, previously undetected founder haplotype.

\section{Population-based association for ALS and FTLD to chromosome 9p}

In 2009, the first ALS GWAS showing association with a locus at chromosome 9p21 was reported by Van Es and colleagues. They identified genome-wide significance with two SNPs, rs2814707 and rs3849942, almost in complete linkage disequilibrium (LD) with each other and located in an LD block of $\sim 80 \mathrm{~kb}$. Also a third SNP in this LD block (rs774359) showed suggestive association (figure 1). This LD block is situated at the telomeric end of the minimally linked candidate region found in the ALS-FTLD families and contains only three genes: part of MOBKL2B, IFNK and C9orf72 (figure 1). Next, data of the first GWAS in FTLD-TDP were suggestive for association of five SNPs (rs774352, rs774351, rs3849942, rs2814707, rs774359) on chromosome 9p21, in the same LD block (Van Deerlin et al., 2010). Subsequently, a Finnish and a British independent ALS GWAS identified genome-wide significance with SNPs rs3849942, rs2814707, rs774359, rs2225389 (Laaksovirta et al., 2010) and with SNPs rs3849942, rs2814707, rs903603 (Shatunov et al., 2010) respectively, all in the same locus at chromosome 9p21. The Finnish study defined a 42-SNP haplotype associated with increased risk of ALS in the Finnish population, located in a $232 \mathrm{~kb}$ LD block which overlaps with the previously reported $80 \mathrm{~kb}$ LD block (van Es et al., 2009) and the $106.5 \mathrm{~kb}$ LD block of the UK study (Shatunov et al., 2010). Because of the unique homogeneous genetic structure of the Finnish isolated population, the extent and structure of LD is different than in other European countries. To date, one study replicated the association of the chr9p21 locus in an ALS-FTLD subpopulation (Rollinson et al., 2011).

To assess the contribution of the chr9p21 risk factor to disease etiology in Belgium, we replicated one of the top SNPs associated in all GWAS reports, rs2814707, in a Belgian population of ALS, ALS-FTLD and FTLD patients. In addition, we performed a metaanalysis of the different published association studies with inclusion of our study. 


\subsection{Replication study chr9p21 GWAS}

We investigated association of the most widely studied GWAS top SNP at chr9p21, rs2814707, in a Flanders-Belgian population of genealogically unrelated patients clinically diagnosed with ALS $(\mathrm{N}=124)$, ALS-FTLD $(\mathrm{N}=21)$ or FTLD $(\mathrm{N}=203)$ according to established consensus criteria (Brooks et al., 2000; Neary et al., 1998), compared to a group of 510 unrelated neurologically healthy control individuals from the same region in Belgium. We genotyped rs2814707 and showed that this SNP is in Hardy-Weinberg Equilibrium. Allelic and genotypic single SNP association was calculated using logistic regression analysis. The SNP showed significant allelic and genotypic association in the total population and highly significant association in the ALS and ALS-FTLD subpopulation reaching a maximal odds ratio of 3.27 in ALS patients homozygous for the minor allele (table 2). In the FTLD subpopulation no association was found, demonstrating that the effect in the total population can entirely be explained by the effect in patients with an ALS phenotype. When we include 21 ALS samples of Bulgarian origin, the relative risk became even higher, compared to Belgians only, indicating that the associated allele is the same between different populations.

\begin{tabular}{|c|c|c|c|c|c|c|c|c|}
\hline \multirow[t]{2}{*}{ SNP ID } & \multirow[t]{2}{*}{ Genotype } & \multirow{2}{*}{$\begin{array}{l}\text { Controls } \\
\mathrm{N}=510 \\
\text { freq }(\%)\end{array}$} & \multicolumn{3}{|c|}{$\begin{array}{l}\text { ALS, ALS-FTLD and FTLD } \\
\qquad N=348\end{array}$} & \multicolumn{3}{|c|}{$\begin{array}{l}\text { ALS and ALS-FTLD } \\
\qquad \mathrm{N}=145\end{array}$} \\
\hline & & & freq $(\%)$ & p-value & OR $(95 \% \mathrm{CI})$ & freq $(\%)$ & p-value & OR $(95 \% \mathrm{CI})$ \\
\hline \multirow[t]{5}{*}{ rs2814707 } & $\mathrm{C}$ & 77.9 & 71.3 & 0.006 & $1.39(1.10-1.75)$ & 67.0 & 0.001 & $1.69(1.25-2.29)$ \\
\hline & $\mathrm{T}$ & 22.1 & 28.7 & & & 33.0 & & \\
\hline & $\mathrm{CC}$ & 59.7 & 50.4 & ref & ref & 43.1 & ref & ref \\
\hline & $\mathrm{CT}$ & 36.5 & 41.8 & 0.08 & $1.31(0.97-1.77)$ & 47.9 & 0.007 & $1.76(1.17-2.64)$ \\
\hline & $\mathrm{TT}$ & 3.8 & 7.8 & 0.008 & $2.41(1.26-4.62)$ & 9.0 & 0.005 & $3.27(1.44-7.41)$ \\
\hline
\end{tabular}

Table 2. Allelic and genotypic association of a GWAS top SNP in the total population and the ALS/ALS-FTLD subpopulation. P-values are corrected for age at onset or inclusion and gender. (OR: odds ratio; $\mathrm{CI}$ : confidence interval)

\subsection{Meta analysis on chromosome 9p21}

We combined the data from the different GWA studies and our study to determine the relative risk of carrying the risk allele on chromosome 9p21. A meta-analysis of the most widely studied SNP on chromosome 9p21 (rs2814707) underscores the presence of a genetic risk factor for ALS and/or FTLD at this locus. Carriers of the rs2814707 minor allele are at increased risk to develop ALS or FTLD $\left(\mathrm{OR}_{\text {meta }} 1.29\right.$ (95\% CI 1.18-1.41), p-value 2.3*10-8 (Figure 4)). When excluding the GWAS cohorts in which the association was first reported (van Es et al., 2009) to exclude bias because of winner's curse, the strength of the association remains similar $\left(\mathrm{OR}_{\text {meta }} 1.32\right.$ (95\% CI 1.17-1.49; p-value 3.5*10-6). Exclusion of three studies, including our own, which combine FTLD and ALS phenotypes would have resulted in an $\mathrm{OR}_{\text {meta }} 1.24$ (95\% CI 1.13-1.36); p-value 3.3*10-6). 


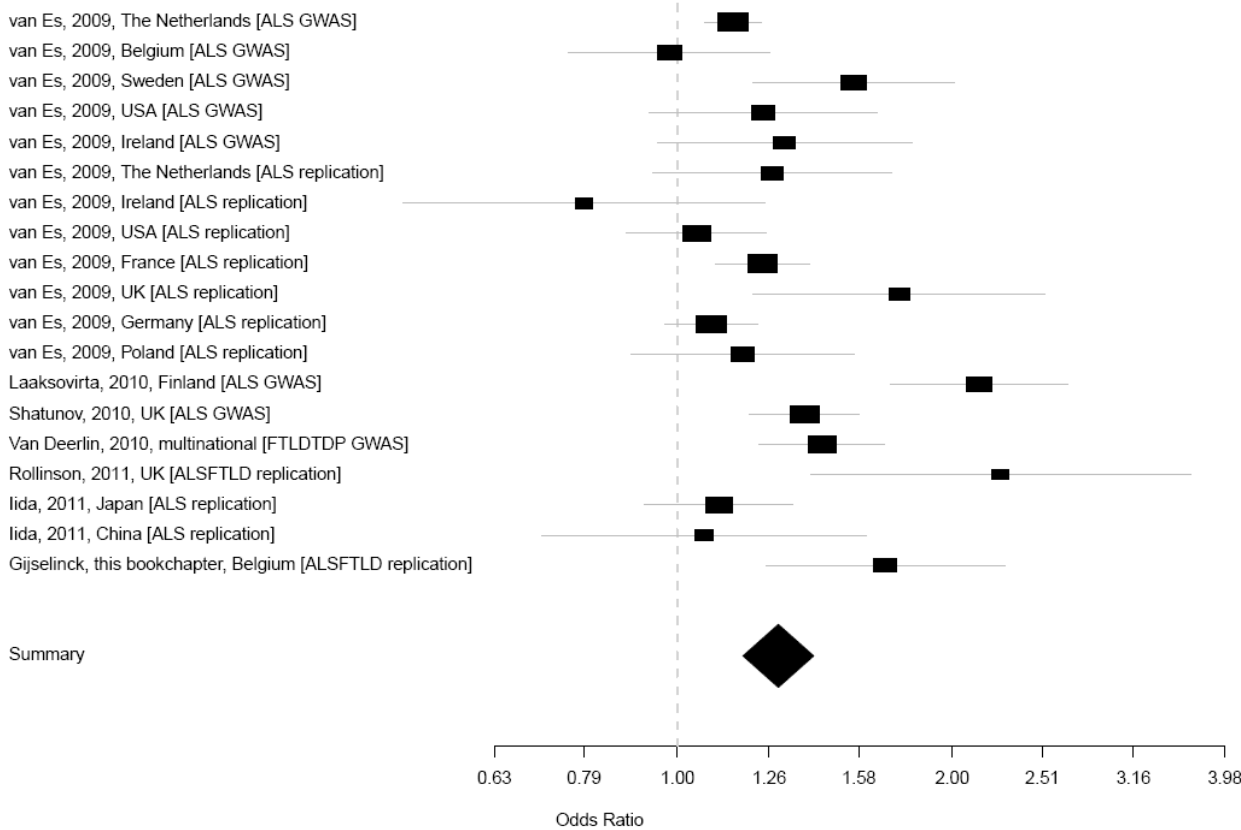

Fig. 4. Forest plot of a random effects meta-analysis of rs2814707. Meta-analysis was conducted in rmeta v2.16, and based on effect estimates and standard errors for the minor allele reported in each individual publication. Odds Ratios and 95\% Confidence Intervals are given for each study separately along with a summary Odds Ratio, of the minor allele relative to the major allele. All 9p21 association studies on ALS, ALS-FTLD and FTLD published until July 2011 were included, in addition to our own unpublished data. For the study of Shatunov and colleagues we only included data on the independent UK cohort, to avoid overlap of datasets with previous studies. From Rollinson et al, only data on the Manchester ALS-FTLD cohort are included.

\section{Discussion and conclusion}

Family-based linkage and population-based association studies in Belgian patients with ALS and/or FTLD provided further evidence for the presence of a major genetic factor on chromosome 9p21 for these diseases.

In the Belgian family DR14 we analyzed the minimally linked region shared in all linked families. We excluded mutations in exons of all known protein-coding genes, in the highest conserved sequences and also copy number mutations of more than $1 \mathrm{~kb}$ were excluded. Further we used next generation sequencing technology to sequence the whole genome of four disease haplotype carriers. We are currently analyzing the first selection of variants. If we are left with only a very small number of putative disease-associated variants, we will analyze the complete sequence of the functional unit in which the remaining variants are located in the complete set of ALS, ALS-FTLD and FTLD patients. 'Functional unit' in this 
context means the gene, regulatory element, conserved element or, in the absence of recognizable elements, $1 \mathrm{~kb}$ flanking each side of the putative mutation. This might identify additional mutations resulting in the same functional defect as the mutations detected in DR14 and further enhance the likelihood of the variant(s) to be disease-related. Finding such variants will provide strong genetic evidence of a disease causing effect of the variants. Alternatively, in case we do not find a mutation in this first selection of variants, we can use more relaxing filters. Taking into account that dbSNP may include rare clinical variants, rare or non-validated dbSNP SNPs will also be considered $(\mathrm{N}=91)$. Also the candidate region can be extended to the next recombinant or to the large DR14 candidate region. Further, regions that are not covered in more than one genome, will be completed using classical sanger sequencing. Finally, structural variants and copy number mutations will be investigated.

More than five years of research in the ALSFTD2 locus in different ALS-FTLD families worldwide did not identify pathogenic mutations yet (table 1), although mutations in two different genes on chromosome 9 outside the minimal candidate region, IFT74 and SIGMAR1, were suggested (Luty et al., 2010; Momeni et al., 2006) but without further confirmation in other families. The fact that the culprit gene is still not found may in part be explained by the fact that families linked with chromosome 9p21 do not all have the same disease haplotype so that different mutations, probably with the same effect on the same gene, are most likely involved. Also, the causal mutations are most likely unusual with respect to position or type. For example, deep intronic mutations or mutations in a distant regulatory element might cause the disease but assessing their effect is rather complicated. Also, identification of small insertions/deletions or inversions is challenging.

In addition, we replicated association in a Belgian cohort of ALS, ALS-FTLD and FTLD patients of two major top SNPs on chromosome 9p21 previously associated in several ALS and FTLD GWA studies. More specifically, we found that the risk haplotype at chromosome 9p21 is most substantially increased in patients with ALS or ALS-FTLD compared to control individuals. The lack of association in the FTLD subpopulation is similar to what was observed in a previous replication study in which association was only found in ALS-FTLD patients (Rollinson et al., 2011). Also, the weakest association signal was found in the FTLD GWAS compared to ALS GWAS. This is the first time that a susceptibility locus for ALS is replicated in different GWA studies and replication studies, underlining the importance of the chromosome 9p21 locus harbouring a risk increasing factor for ALS (and ALS-FTLD) across multiple populations with a high relative risk of disease susceptibility. We are further characterizing this genetic association to reduce the associated region in the Belgian population. We are finemapping the chromosome 9p risk haplotype in great detail in our ALS, FTLD, ALS-FTLD patient cohorts by making a high density SNP map of the complete LD block and using extended association analyses of series of known and newly identified variants in the LD block. These variants were identified in previous publications, hapmap, 1000 Genomes Project and extended genomic sequencing efforts of the linkage disequilibrium block in a selection of ALS and ALS-FTLD patients carrying the associated allele of the GWAS SNPs in a homozygous or heterozygous state. This will finally result in the identification of the functional variant explaining the strong association in the chromosome 9 p21 region.

The observation that the chromosome 9p21 region is harboring both disease-causing variants and susceptibility factors with high penetrance, might suggest that different genetic variants with variable degree of biological consequences might be involved. Alternatively, 
one genetic defect might act as high penetrant susceptibility factor in sporadic patients and as disease-causing factor with reduced penetrance in ALS-FTLD families, carrying also other disease modifying factors. In this respect it is interesting to note that in our studied belgian family DR14 all patients carry in addition to the disease haplotype at chromosome 9p21 also a haplotype in a novel locus at chromosome 14q32, possibly harboring a disease modifying gene (Gijselinck et al., 2010) and of which the sequences are present in the whole genome sequencing data of the family. Combining the family-based and the population-based approach to ultimately find the gene with one or more genetic defects would be of great value. For example, prioritizing the associated LD block in the whole genome sequence analysis of the family could be useful. Further, since in the associated LD block only three genes are located (IFNK, C9orf72, MOBKL2B) (figure 1), we could focus on these genes with respect to expression and dosage studies (eg. single exon deletions or duplications) in the family. Also, the region in and around the associated LD block can be saturated with STR markers for sharing studies with the DR14 family to detect a small founder haplotype. Combining all these comprehensive data will bring us closer to the identification of the chromosome 9 gene. As long as the genetic defect underlying linkage and association is not known, the full epidemiological impact of the chromosome 9p gene in familial and nonfamilial forms of ALS, ALS-FTLD and FTLD cannot be determined. However, the combined evidence emerging from all molecular genetic studies in chromosome 9p21-linked families and in chromosome 9p21 associated ALS/FTLD populations, suggests it is the most important genetic factor contributing to disease in the center of the disease spectrum linking ALS and FTLD (table 1). Moreover, next to the chr9p21 conclusively linked ALS-FTLD families, several other (smaller) families were also reported without conclusive linkage but with several indications pointing towards the presence of a segregating haplotype in the ALSFTD2 locus (Krueger et al., 2009; Le Ber et al., 2009; Momeni et al., 2006; Pearson et al., 2011; Valdmanis et al., 2007; Yan et al., 2008) (table 1). Identification of this major gene will undoubtedly be a steppingstone for subsequent cell biological studies aiming at better understanding of the pathobiology of neurodegenerative processes leading to ALS and FTLD.

\section{Acknowledgment}

We are grateful to the patients for their cooperation. We further acknowledge the contribution of personnel of the VIB Genetic Service Facility (www.vibgeneticservicefacility.be). This research of the authors was in part funded by the Special Research Fund of the University of Antwerp, the Research Foundation Flanders (FWO-F), the Institute for Science and Technology - Flanders (IWT-F), the Methusalem excellence grant of the Flemish Government, the Interuniversity Attraction Poles program (IUAP) P6/43 of the Belgian Science Policy Office, the Stichting Alzheimer Onderzoek (SAO-FRMA). I.G. is holding a postdoctoral fellowship of FWO-F.

\section{References}

Arai, T., Hasegawa, M., Akiyama, H., Ikeda, K., Nonaka, T., Mori, H., Mann, D., Tsuchiya, K., Yoshida, M., Hashizume, Y. \& Oda, T. (2006). TDP-43 is a component of ubiquitin-positive tau-negative inclusions in frontotemporal lobar degeneration and amyotrophic lateral sclerosis. Biochem Biophys Res Commun, 351, 3, 602-611 
Baker, M., Mackenzie, I.R., Pickering-Brown, S.M., Gass, J., Rademakers, R., Lindholm, C., Snowden, J., Adamson, J., Sadovnick, A.D., Rollinson, S., Cannon, A., Dwosh, E., Neary, D., Melquist, S., Richardson, A., Dickson, D., Berger, Z., Eriksen, J., Robinson, T., Zehr, C., Dickey, C.A., Crook, R., McGowan, E., Mann, D., Boeve, B., Feldman, H. \& Hutton, M. (2006). Mutations in progranulin cause tau-negative frontotemporal dementia linked to chromosome 17. Nature, 442, 7105, 916-919

Boxer, A.L., Mackenzie, I.R., Boeve, B.F., Baker, M., Seeley, W.W., Crook, R., Feldman, H., Hsiung, G.Y., Rutherford, N., Laluz, V., Whitwell, J., Foti, D., McDade, E., Molano, J., Karydas, A., Wojtas, A., Goldman, J., Mirsky, J., Sengdy, P., Dearmond, S., Miller, B.L. \& Rademakers, R. (2010). Clinical, neuroimaging and neuropathological features of a new chromosome 9p-linked FTD-ALS family. J Neurol Neurosurg Psychiatry

Brooks, B.R., Miller, R.G., Swash, M. \& Munsat, T.L. (2000). El Escorial revisited: revised criteria for the diagnosis of amyotrophic lateral sclerosis. Amyotroph Lateral Scler Other Motor Neuron Disord, 1, 5, 293-299

Cooper, G.M., Zerr, T., Kidd, J.M., Eichler, E.E. \& Nickerson, D.A. (2008). Systematic assessment of copy number variant detection via genome-wide SNP genotyping. Nat Genet, 40, 10, 1199-1203

Cruts, M., Gijselinck, I., van der Zee, J., Engelborghs, S., Wils, H., Pirici, D., Rademakers, R., Vandenberghe, R., Dermaut, B., Martin, J.J., van Duijn, C., Peeters, K., Sciot, R., Santens, P., de Pooter, T., Mattheijssens, M., Van den Broeck, M., Cuijt, I., Vennekens, K., De Deyn, P.P., Kumar-Singh, S. \& Van Broeckhoven, C. (2006). Null mutations in progranulin cause ubiquitin-positive frontotemporal dementia linked to chromosome 17q21. Nature, 442, 7105, 920-924

Drmanac, R., Sparks, A.B., Callow, M.J., Halpern, A.L., Burns, N.L., Kermani, B.G., Carnevali, P., Nazarenko, I., Nilsen, G.B., Yeung, G., Dahl, F., Fernandez, A., Staker, B., Pant, K.P., Baccash, J., Borcherding, A.P., Brownley, A., Cedeno, R., Chen, L., Chernikoff, D., Cheung, A., Chirita, R., Curson, B., Ebert, J.C., Hacker, C.R., Hartlage, R., Hauser, B., Huang, S., Jiang, Y., Karpinchyk, V., Koenig, M., Kong, C., Landers, T., Le, C., Liu, J., McBride, C.E., Morenzoni, M., Morey, R.E., Mutch, K., Perazich, H., Perry, K., Peters, B.A., Peterson, J., Pethiyagoda, C.L., Pothuraju, K., Richter, C., Rosenbaum, A.M., Roy, S., Shafto, J., Sharanhovich, U., Shannon, K.W., Sheppy, C.G., Sun, M., Thakuria, J.V., Tran, A., Vu, D., Zaranek, A.W., Wu, X., Drmanac, S., Oliphant, A.R., Banyai, W.C., Martin, B., Ballinger, D.G., Church, G.M. \& Reid, C.A. (2010). Human genome sequencing using unchained base reads on self-assembling DNA nanoarrays. Science, 327, 5961, 78-81

Gijselinck, I., Engelborghs, S., Maes, G., Cuijt, I., Peeters, K., Mattheijssens, M., Joris, G., Cras, P., Martin, J.J., De Deyn, P.P., Kumar-Singh, S., Van Broeckhoven, C. \& Cruts, M. (2010). Identification of 2 Loci at chromosomes 9 and 14 in a multiplex family with frontotemporal lobar degeneration and amyotrophic lateral sclerosis. Arch Neurol, 67, 5, 606-616

Gitcho, M.A., Baloh, R.H., Chakraverty, S., Mayo, K., Norton, J.B., Levitch, D., Hatanpaa, K.J., White, C.L., III, Bigio, E.H., Caselli, R., Baker, M., Al Lozi, M.T., Morris, J.C., Pestronk, A., Rademakers, R., Goate, A.M. \& Cairns, N.J. (2008). TDP-43 A315T mutation in familial motor neuron disease. Ann Neurol, 63, 4, 535-538 
Greenway, M.J., Andersen, P.M., Russ, C., Ennis, S., Cashman, S., Donaghy, C., Patterson, V., Swingler, R., Kieran, D., Prehn, J., Morrison, K.E., Green, A., Acharya, K.R., Brown, R.H., Jr. \& Hardiman, O. (2006). ANG mutations segregate with familial and 'sporadic' amyotrophic lateral sclerosis. Nat Genet, 38, 4, 411-413

Hutton, M., Lendon, C.L., Rizzu, P., Baker, M., Froelich, S., Houlden, H., Pickering-Brown, S., Chakraverty, S., Isaacs, A., Grover, A., Hackett, J., Adamson, J., Lincoln, S., Dickson, D., Davies, P., Petersen, R.C., Stevens, M., de Graaff, E., Wauters, E., van Baren, J., Hillebrand, M., Joosse, M., Kwon, J.M., Nowotny, P., Che, L.K., Norton, J., Morris, J.C., Reed, L.A., Trojanowski, J., Basun, H., Lannfelt, L., Neystat, M., Fahn, S., Dark, F., Tannenberg, T., Dodd, P.R., Hayward, N., Kwok, J.B., Schofield, P.R., Andreadis, A., Snowden, J., Craufurd, D., Neary, D., Owen, F., Oostra, B.A., Hardy, J., Goate, A., van Swieten, J., Mann, D., Lynch, T. \& Heutink, P. (1998). Association of missense and 5'-splice-site mutations in tau with the inherited dementia FTDP17. Nature, 393, 6686, 702-705

Johnson, J.O., Mandrioli, J., Benatar, M., Abramzon, Y., Van Deerlin, V.M., Trojanowski, J.Q., Gibbs, J.R., Brunetti, M., Gronka, S., Wuu, J., Ding, J., McCluskey, L., MartinezLage, M., Falcone, D., Hernandez, D.G., Arepalli, S., Chong, S., Schymick, J.C., Rothstein, J., Landi, F., Wang, Y.D., Calvo, A., Mora, G., Sabatelli, M., Monsurro, M.R., Battistini, S., Salvi, F., Spataro, R., Sola, P., Borghero, G., Galassi, G., Scholz, S.W., Taylor, J.P., Restagno, G., Chio, A. \& Traynor, B.J. (2010). Exome sequencing reveals VCP mutations as a cause of familial ALS. Neuron, 68, 5, 857-864

Kabashi, E., Valdmanis, P.N., Dion, P., Spiegelman, D., McConkey, B.J., Vande, V.C., Bouchard, J.P., Lacomblez, L., Pochigaeva, K., Salachas, F., Pradat, P.F., Camu, W., Meininger, V., Dupre, N. \& Rouleau, G.A. (2008). TARDBP mutations in individuals with sporadic and familial amyotrophic lateral sclerosis. Nat Genet, 40, $5,572-574$

Kovacs, G.G., Murrell, J.R., Horvath, S., Haraszti, L., Majtenyi, K., Molnar, M.J., Budka, H., Ghetti, B. \& Spina, S. (2009). TARDBP variation associated with frontotemporal dementia, supranuclear gaze palsy, and chorea. Mov Disord, 24, 12, 1843-1847

Krueger, K.A., Tsuji, S., Fukuda, Y., Takahashi, Y., Goto, J., Mitsui, J., Ishiura, H., Dalton, J.C., Miller, M.B., Day, J.W. \& Ranum, L.P. (2009). SNP haplotype mapping in a small ALS family. PLoS One, 4, 5, e5687

Kwiatkowski, T.J., Jr., Bosco, D.A., Leclerc, A.L., Tamrazian, E., Vanderburg, C.R., Russ, C., Davis, A., Gilchrist, J., Kasarskis, E.J., Munsat, T., Valdmanis, P., Rouleau, G.A., Hosler, B.A., Cortelli, P., de Jong, P.J., Yoshinaga, Y., Haines, J.L., Pericak-Vance, M.A., Yan, J., Ticozzi, N., Siddique, T., McKenna-Yasek, D., Sapp, P.C., Horvitz, H.R., Landers, J.E. \& Brown, R.H., Jr. (2009). Mutations in the FUS/TLS gene on chromosome 16 cause familial amyotrophic lateral sclerosis. Science, 323, 5918, 1205 1208

Laaksovirta, H., Peuralinna, T., Schymick, J.C., Scholz, S.W., Lai, S.L., Myllykangas, L., Sulkava, R., Jansson, L., Hernandez, D.G., Gibbs, J.R., Nalls, M.A., Heckerman, D., Tienari, P.J. \& Traynor, B.J. (2010). Chromosome 9p21 in amyotrophic lateral sclerosis in Finland: a genome-wide association study. Lancet Neurol, 9, 10, 978-985

Le Ber, I., Camuzat, A., Berger, E., Hannequin, D., Laquerriere, A., Golfier, V., Seilhean, D., Viennet, G., Couratier, P., Verpillat, P., Heath, S., Camu, W., Martinaud, O., Lacomblez, L., Vercelletto, M., Salachas, F., Sellal, F., Didic, M., Thomas-Anterion, 
C., Puel, M., Michel, B.F., Besse, C., Duyckaerts, C., Meininger, V., Campion, D., Dubois, B. \& Brice, A. (2009). Chromosome 9p-linked families with frontotemporal dementia associated with motor neuron disease. Neurology, 72, 19, 1669-1676

Lillo, P. \& Hodges, J.R. (2009). Frontotemporal dementia and motor neurone disease: overlapping clinic-pathological disorders. J Clin Neurosci, 16, 9, 1131-1135

Lomen-Hoerth, C., Murphy, J., Langmore, S., Kramer, J.H., Olney, R.K. \& Miller, B. (2003). Are amyotrophic lateral sclerosis patients cognitively normal? Neurology, 60, 7, 1094-1097

Luty, A.A., Kwok, J.B., Dobson-Stone, C., Loy, C.T., Coupland, K.G., Karlstrom, H., Sobow, T., Tchorzewska, J., Maruszak, A., Barcikowska, M., Panegyres, P.K., Zekanowski, C., Brooks, W.S., Williams, K.L., Blair, I.P., Mather, K.A., Sachdev, P.S., Halliday, G.M. \& Schofield, P.R. (2010). Sigma nonopioid intracellular receptor 1 mutations cause frontotemporal lobar degeneration-motor neuron disease. Ann Neurol, 68, 5, 639-649

Luty, A.A., Kwok, J.B., Thompson, E.M., Blumbergs, P., Brooks, W.S., Loy, C.T., DobsonStone, C., Panegyres, P.K., Hecker, J., Nicholson, G.A., Halliday, G.M. \& Schofield, P.R. (2008). Pedigree with frontotemporal lobar degeneration--motor neuron disease and Tar DNA binding protein-43 positive neuropathology: genetic linkage to chromosome 9. BMC Neurol, 8, 32

Momeni, P., Schymick, J., Jain, S., Cookson, M.R., Cairns, N.J., Greggio, E., Greenway, M.J., Berger, S., Pickering-Brown, S., Chio, A., Fung, H.C., Holtzman, D.M., Huey, E.D., Wassermann, E.M., Adamson, J., Hutton, M.L., Rogaeva, E., George-Hyslop, P., Rothstein, J.D., Hardiman, O., Grafman, J., Singleton, A., Hardy, J. \& Traynor, B.J. (2006). Analysis of IFT74 as a candidate gene for chromosome 9p-linked ALS-FTD. BMC Neurol, 6, 44

Morita, M., Al Chalabi, A., Andersen, P.M., Hosler, B., Sapp, P., Englund, E., Mitchell, J.E., Habgood, J.J., de Belleroche, J., Xi, J., Jongjaroenprasert, W., Horvitz, H.R., Gunnarsson, L.G. \& Brown, R.H., Jr. (2006). A locus on chromosome 9p confers susceptibility to ALS and frontotemporal dementia. Neurology, 66, 6, 839-844

Neary, D., Snowden, J.S., Gustafson, L., Passant, U., Stuss, D., Black, S., Freedman, M., Kertesz, A., Robert, P.H., Albert, M., Boone, K., Miller, B.L., Cummings, J. \& Benson, D.F. (1998). Frontotemporal lobar degeneration: a consensus on clinical diagnostic criteria. Neurology, 51, 6, 1546-1554

Neumann, M., Sampathu, D.M., Kwong, L.K., Truax, A.C., Micsenyi, M.C., Chou, T.T., Bruce, J., Schuck, T., Grossman, M., Clark, C.M., McCluskey, L.F., Miller, B.L., Masliah, E., Mackenzie, I.R., Feldman, H., Feiden, W., Kretzschmar, H.A., Trojanowski, J.Q. \& Lee, V.M. (2006). Ubiquitinated TDP-43 in frontotemporal lobar degeneration and amyotrophic lateral sclerosis. Science, 314, 5796, 130-133

Pearson, J.P., Williams, N.M., Majounie, E., Waite, A., Stott, J., Newsway, V., Murray, A., Hernandez, D., Guerreiro, R., Singleton, A.B., Neal, J. \& Morris, H.R. (2011). Familial frontotemporal dementia with amyotrophic lateral sclerosis and a shared haplotype on chromosome 9p. J Neurol, 258, 4, 647-655

Ravasi, T., Suzuki, H., Cannistraci, C.V., Katayama, S., Bajic, V.B., Tan, K., Akalin, A., Schmeier, S., Kanamori-Katayama, M., Bertin, N., Carninci, P., Daub, C.O., Forrest, A.R., Gough, J., Grimmond, S., Han, J.H., Hashimoto, T., Hide, W., Hofmann, O., Kamburov, A., Kaur, M., Kawaji, H., Kubosaki, A., Lassmann, T., van, N.E., 
MacPherson, C.R., Ogawa, C., Radovanovic, A., Schwartz, A., Teasdale, R.D., Tegner, J., Lenhard, B., Teichmann, S.A., Arakawa, T., Ninomiya, N., Murakami, K., Tagami, M., Fukuda, S., Imamura, K., Kai, C., Ishihara, R., Kitazume, Y., Kawai, J., Hume, D.A., Ideker, T. \& Hayashizaki, Y. (2010). An atlas of combinatorial transcriptional regulation in mouse and man. Cell, 140, 5, 744-752

Ringholz, G.M., Appel, S.H., Bradshaw, M., Cooke, N.A., Mosnik, D.M. \& Schulz, P.E. (2005). Prevalence and patterns of cognitive impairment in sporadic ALS. Neurology, 65, 4, 586-590

Roach, J.C., Glusman, G., Smit, A.F., Huff, C.D., Hubley, R., Shannon, P.T., Rowen, L., Pant, K.P., Goodman, N., Bamshad, M., Shendure, J., Drmanac, R., Jorde, L.B., Hood, L. \& Galas, D.J. (2010). Analysis of Genetic Inheritance in a Family Quartet by WholeGenome Sequencing. Science

Rollinson, S., Mead, S., Snowden, J., Richardson, A., Rohrer, J., Halliwell, N., Usher, S., Neary, D., Mann, D., Hardy, J. \& Pickering-Brown, S. (2011). Frontotemporal lobar degeneration genome wide association study replication confirms a risk locus shared with amyotrophic lateral sclerosis. Neurobiol Aging, 32, 4, 758-7

Rosen, D.R., Siddique, T., Patterson, D., Figlewicz, D.A., Sapp, P., Hentati, A., Donaldson, D., Goto, J., O'Regan, J.P., Deng, H.X. \& . (1993). Mutations in Cu/Zn superoxide dismutase gene are associated with familial amyotrophic lateral sclerosis. Nature, 362, 6415, 59-62

Rosso, S.M., Donker, K.L., Baks, T., Joosse, M., de, K., I, Pijnenburg, Y., de Jong, D., Dooijes, D., Kamphorst, W., Ravid, R., Niermeijer, M.F., Verheij, F., Kremer, H.P., Scheltens, P., van Duijn, C.M., Heutink, P. \& van Swieten, J.C. (2003). Frontotemporal dementia in The Netherlands: patient characteristics and prevalence estimates from a population-based study. Brain, 126, Pt 9, 2016-2022

Rowland, L.P. \& Shneider, N.A. (2001). Amyotrophic lateral sclerosis. N Engl J Med, 344, 22, 1688-1700

Sampathu, D.M., Neumann, M., Kwong, L.K., Chou, T.T., Micsenyi, M., Truax, A., Bruce, J., Grossman, M., Trojanowski, J.Q. \& Lee, V.M. (2006). Pathological heterogeneity of frontotemporal lobar degeneration with ubiquitin-positive inclusions delineated by ubiquitin immunohistochemistry and novel monoclonal antibodies. Am J Pathol, $169,4,1343-1352$

Sela, N., Mersch, B., Gal-Mark, N., Lev-Maor, G., Hotz-Wagenblatt, A. \& Ast, G. (2007). Comparative analysis of transposed element insertion within human and mouse genomes reveals Alu's unique role in shaping the human transcriptome. Genome Biol, 8, 6, R127

Shatunov, A., Mok, K., Newhouse, S., Weale, M.E., Smith, B., Vance, C., Johnson, L., Veldink, J.H., van Es, M.A., van den Berg, L.H., Robberecht, W., Van, D.P., Hardiman, O., Farmer, A.E., Lewis, C.M., Butler, A.W., Abel, O., Andersen, P.M., Fogh, I., Silani, V., Chio, A., Traynor, B.J., Melki, J., Meininger, V., Landers, J.E., McGuffin, P., Glass, J.D., Pall, H., Leigh, P.N., Hardy, J., Brown, R.H., Jr., Powell, J.F., Orrell, R.W., Morrison, K.E., Shaw, P.J., Shaw, C.E. \& Al-Chalabi, A. (2010). Chromosome 9p21 in sporadic amyotrophic lateral sclerosis in the UK and seven other countries: a genome-wide association study. Lancet Neurol, 9, 10, 986-994

Skibinski, G., Parkinson, N.J., Brown, J.M., Chakrabarti, L., Lloyd, S.L., Hummerich, H., Nielsen, J.E., Hodges, J.R., Spillantini, M.G., Thusgaard, T., Brandner, S., Brun, A., 
Rossor, M.N., Gade, A., Johannsen, P., Sorensen, S.A., Gydesen, S., Fisher, E.M. \& Collinge, J. (2005). Mutations in the endosomal ESCRTIII-complex subunit CHMP2B in frontotemporal dementia. Nat Genet, 37, 8, 806-808

Sreedharan, J., Blair, I.P., Tripathi, V.B., Hu, X., Vance, C., Rogelj, B., Ackerley, S., Durnall, J.C., Williams, K.L., Buratti, E., Baralle, F., de Belleroche, J., Mitchell, J.D., Leigh, P.N., Al Chalabi, A., Miller, C.C., Nicholson, G. \& Shaw, C.E. (2008). TDP-43 mutations in familial and sporadic amyotrophic lateral sclerosis. Science, 319, 5870, $1668-1672$

Valdmanis, P.N., Dupre, N., Bouchard, J.P., Camu, W., Salachas, F., Meininger, V., Strong, M. \& Rouleau, G.A. (2007). Three families with amyotrophic lateral sclerosis and frontotemporal dementia with evidence of linkage to chromosome 9p. Arch Neurol, $64,2,240-245$

Van Deerlin, V.M., Leverenz, J.B., Bekris, L.M., Bird, T.D., Yuan, W., Elman, L.B., Clay, D., Wood, E.M., Chen-Plotkin, A.S., Martinez-Lage, M., Steinbart, E., McCluskey, L., Grossman, M., Neumann, M., Wu, I.L., Yang, W.S., Kalb, R., Galasko, D.R., Montine, T.J., Trojanowski, J.Q., Lee, V.M., Schellenberg, G.D. \& Yu, C.E. (2008). TARDBP mutations in amyotrophic lateral sclerosis with TDP-43 neuropathology: a genetic and histopathological analysis. Lancet Neurol, 7, 5, 409-416

Van Deerlin, V.M., Sleiman, P.M., Martinez-Lage, M., Chen-Plotkin, A., Wang, L.S., GraffRadford, N.R., Dickson, D.W., Rademakers, R., Boeve, B.F., Grossman, M., Arnold, S.E., Mann, D.M., Pickering-Brown, S.M., Seelaar, H., Heutink, P., van Swieten, J.C., Murrell, J.R., Ghetti, B., Spina, S., Grafman, J., Hodges, J., Spillantini, M.G., Gilman, S., Lieberman, A.P., Kaye, J.A., Woltjer, R.L., Bigio, E.H., Mesulam, M., Al-Sarraj, S., Troakes, C., Rosenberg, R.N., White, C.L., III, Ferrer, I., Llado, A., Neumann, M., Kretzschmar, H.A., Hulette, C.M., Welsh-Bohmer, K.A., Miller, B.L., Alzualde, A., de Munain, A.L., McKee, A.C., Gearing, M., Levey, A.I., Lah, J.J., Hardy, J., Rohrer, J.D., Lashley, T., Mackenzie, I.R., Feldman, H.H., Hamilton, R.L., Dekosky, S.T., van der Zee, J., Kumar-Singh, S., Van, B.C., Mayeux, R., Vonsattel, J.P., Troncoso, J.C., Kril, J.J., Kwok, J.B., Halliday, G.M., Bird, T.D., Ince, P.G., Shaw, P.J., Cairns, N.J., Morris, J.C., McLean, C.A., DeCarli, C., Ellis, W.G., Freeman, S.H., Frosch, M.P., Growdon, J.H., Perl, D.P., Sano, M., Bennett, D.A., Schneider, J.A., Beach, T.G., Reiman, E.M., Woodruff, B.K., Cummings, J., Vinters, H.V., Miller, C.A., Chui, H.C., Alafuzoff, I., Hartikainen, P., Seilhean, D., Galasko, D., Masliah, E., Cotman, C.W., Tunon, M.T., Martinez, M.C., Munoz, D.G., Carroll, S.L., Marson, D., Riederer, P.F., Bogdanovic, N., Schellenberg, G.D., Hakonarson, H., Trojanowski, J.Q. \& Lee, V.M. (2010). Common variants at 7p21 are associated with frontotemporal lobar degeneration with TDP-43 inclusions. Nat Genet, 42, 3, 234-239 van Es, M.A., Veldink, J.H., Saris, C.G., Blauw, H.M., van Vught, P.W., Birve, A., Lemmens, R., Schelhaas, H.J., Groen, E.J., Huisman, M.H., Van Der Kooi, A.J., De, V.M., Dahlberg, C., Estrada, K., Rivadeneira, F., Hofman, A., Zwarts, M.J., van Doormaal, P.T., Rujescu, D., Strengman, E., Giegling, I., Muglia, P., Tomik, B., Slowik, A., Uitterlinden, A.G., Hendrich, C., Waibel, S., Meyer, T., Ludolph, A.C., Glass, J.D., Purcell, S., Cichon, S., Nothen, M.M., Wichmann, H.E., Schreiber, S., Vermeulen, S.H., Kiemeney, L.A., Wokke, J.H., Cronin, S., McLaughlin, R.L., Hardiman, O., Fumoto, K., Pasterkamp, R.J., Meininger, V., Melki, J., Leigh, P.N., Shaw, C.E., Landers, J.E., Al-Chalabi, A., Brown, R.H., Jr., Robberecht, W., Andersen, P.M., 
Ophoff, R.A. \& van den Berg, L.H. (2009). Genome-wide association study identifies 19p13.3 (UNC13A) and 9p21.2 as susceptibility loci for sporadic amyotrophic lateral sclerosis. Nat Genet, 41, 10, 1083-1087

Van Langenhove, T., van der Zee, J., Sleegers, K., Engelborghs, S., Vandenberghe, R., Gijselinck, I., Van den Broeck, M., Mattheijssens, M., Peeters, K., De Deyn, P.P., Cruts, M. \& Van, B.C. (2010). Genetic contribution of FUS to frontotemporal lobar degeneration. Neurology, 74, 5, 366-371

Vance, C., Al Chalabi, A., Ruddy, D., Smith, B.N., Hu, X., Sreedharan, J., Siddique, T., Schelhaas, H.J., Kusters, B., Troost, D., Baas, F., de, J., V \& Shaw, C.E. (2006). Familial amyotrophic lateral sclerosis with frontotemporal dementia is linked to a locus on chromosome 9p13.2-21.3. Brain, 129, Pt 4, 868-876

Vance, C., Rogelj, B., Hortobagyi, T., De Vos, K.J., Nishimura, A.L., Sreedharan, J., Hu, X., Smith, B., Ruddy, D., Wright, P., Ganesalingam, J., Williams, K.L., Tripathi, V., Al Saraj, S., Al Chalabi, A., Leigh, P.N., Blair, I.P., Nicholson, G., de Belleroche, J., Gallo, J.M., Miller, C.C. \& Shaw, C.E. (2009). Mutations in FUS, an RNA processing protein, cause familial amyotrophic lateral sclerosis type 6 . Science, 323, 5918, 12081211

Watts, G.D., Wymer, J., Kovach, M.J., Mehta, S.G., Mumm, S., Darvish, D., Pestronk, A., Whyte, M.P. \& Kimonis, V.E. (2004). Inclusion body myopathy associated with Paget disease of bone and frontotemporal dementia is caused by mutant valosincontaining protein. Nat Genet, 36, 4, 377-381

Yan J, Slifer S, Siddique N, Chen W, Yong S, Erdong L, Haines JL, Pericak-Vance M, Siddique T. 2008. Fine-Mapping and Candidate Gene Sequencing of the Chromosome 9p Locus of ALS/FTD.

Yokoseki, A., Shiga, A., Tan, C.F., Tagawa, A., Kaneko, H., Koyama, A., Eguchi, H., Tsujino, A., Ikeuchi, T., Kakita, A., Okamoto, K., Nishizawa, M., Takahashi, H. \& Onodera, O. (2008). TDP-43 mutation in familial amyotrophic lateral sclerosis. Ann Neurol, 63, $4,538-542$ 
AMYOTROPHIC

LATERAL SCLEROSIS

Eaced by Marton H. maver

\section{Amyotrophic Lateral Sclerosis}

Edited by Prof. Martin Maurer
ISBN 978-953-307-806-9

Hard cover, 718 pages

Publisher InTech

Published online 20, January, 2012

Published in print edition January, 2012

Though considerable amount of research, both pre-clinical and clinical, has been conducted during recent years, Amyotrophic Lateral Sclerosis (ALS) remains one of the mysterious diseases of the 21 st century. Great efforts have been made to develop pathophysiological models and to clarify the underlying pathology, and with novel instruments in genetics and transgenic techniques, the aim for finding a durable cure comes into scope. On the other hand, most pharmacological trials failed to show a benefit for ALS patients. In this book, the reader will find a compilation of state-of-the-art reviews about the etiology, epidemiology, and pathophysiology of ALS, the molecular basis of disease progression and clinical manifestations, the genetics familial ALS, as well as novel diagnostic criteria in the field of electrophysiology. An overview over all relevant pharmacological trials in ALS patients is also included, while the book concludes with a discussion on current advances and future trends in ALS research.

\section{How to reference}

In order to correctly reference this scholarly work, feel free to copy and paste the following:

Ilse Gijselinck, Kristel Sleegers, Christine Van Broeckhoven and Marc Cruts (2012). A Major Genetic Factor at Chromosome 9p Implicated in Amyotrophic Lateral Sclerosis (ALS) and Frontotemporal Lobar Degeneration (FTLD), Amyotrophic Lateral Sclerosis, Prof. Martin Maurer (Ed.), ISBN: 978-953-307-806-9, InTech, Available from: http://www.intechopen.com/books/amyotrophic-lateral-sclerosis/a-major-genetic-factor-at-chromosome$9 \mathrm{p}$-implicated-in-amyotrophic-lateral-sclerosis-als-and-frontote

\section{INTECH}

open science | open minds

\section{InTech Europe}

University Campus STeP Ri

Slavka Krautzeka 83/A

51000 Rijeka, Croatia

Phone: +385 (51) 770447

Fax: +385 (51) 686166

www.intechopen.com

\section{InTech China}

Unit 405, Office Block, Hotel Equatorial Shanghai

No.65, Yan An Road (West), Shanghai, 200040, China

中国上海市延安西路65号上海国际贵都大饭店办公楼 405 单元

Phone: +86-21-62489820

Fax: $+86-21-62489821$ 
(C) 2012 The Author(s). Licensee IntechOpen. This is an open access article distributed under the terms of the Creative Commons Attribution 3.0 License, which permits unrestricted use, distribution, and reproduction in any medium, provided the original work is properly cited. 